\title{
Reovirus type 2-induced diabetes in mice prevented by immunosuppression and thymic hormone
}

\author{
T. Onodera ${ }^{1}$, T. Taniguchi ${ }^{1}$, K. Yoshihara ${ }^{1}$, S. Shimizu $^{1}$, M. Sato ${ }^{1}$ and T. Hayashi ${ }^{2}$ \\ ${ }^{1}$ National Institute of Animal Health, Tsukuba, Ibaraki and \\ ${ }^{2}$ Department of Veterinary Pathology, University of Yamaguchi, Yamaguchi, Japan
}

\begin{abstract}
Summary. Reovirus type 2 that had been isolated from a cow with diarrhoea and passaged in bovine kidney cell culture produced a Type 1 (insulin-dependent) diabetes-like syndrome when inoculated into $\mathrm{NC}$ mice. The infection resulted in insulitis and destruction of islet cells. Viral antigens were found in islet cells by staining with fluorescein-labelled antibody to reovirus type 2 . The destruction of islet cells resulted in abnormalities shown on glucose tolerance testing. Studies on the susceptibility of the host showed that only certain strains of mice had overtly abnormal glucose tolerance tests when infected with reovirus type 2 . To assess the immuno-
\end{abstract}

logical role in the pathogenesis of reovirus type 2-induced diabetes, infected mice were subjected to immunosuppressive or thymic hormone treatment. The administration of either anti-thymocyte serum or serum thymic factor reduced or prevented the development of the diabetes-like syndrome, while Arg-Lys-Asp-Val-Try did not show any therapeutic effects.

Key words: Reovirus type 2 , diabetes, serum thymic factor, immunosuppression, insulitis.
A virus might cause some cases of Type 1 (insulin-dependent) diabetes mellitus by infecting and destroying pancreatic Beta cells [1]. Mumps, rubella and members of the coxsackievirus B group (particularly B4) have most frequently been suggested as possible causes of Type 1 diabetes [1-6]. A coxsackievirus B4 variant, isolated from the pancreas of a 10-year-old child who died from diabetic ketoacidosis, produced diabetes in SJL mice by infecting and destroying Beta cells [7].

We have previously shown that reovirus type 1 and 3 , passaged in murine pancreatic Beta-cell cultures, produced an insulitis when the virus was inoculated into 1-2day old mice [8,9]. In the present experiments, reovirus type 2 (reo-2) was used to determine whether this virus was diabetogenic to mice, and whether reo-2-induced diabetes could be suppressed by immunosuppression or thymic hormone treatment. Histopathology, immunofluorescence and glucose tolerance tests were used to evaluate the diabetogenicity of the virus, and the effect of immunosuppression or hormone treatment against virus-induced diabetes was investigated.

\section{Materials and methods}

\section{Animals and virus}

Male and female 2-3-day old NC mice were infected i.p. with BN-77 strain of reo-2 [10] which had been isolated from a cow with diarrhoea and passaged 10 times in bovine kidney cells [11]. This virus was originally isolated in our institute. The infectious titre of reo-2 was determined by inoculating confluent HmLu-1 cell [10] monolayers (60 $\mathrm{mm}$ dishes) with $0.2 \mathrm{ml}$ of appropriate dilutions of the virus sample. After adsorption for $1 \mathrm{~h}$ at $37^{\circ} \mathrm{C}$, the monolayers were covered with agarose medium [1\% (weight/volume) agarose with Eagle's MEM and 5\% fetal bovine serum]. Monolayers were subsequently stained on day 6 with $1: 40,000$ dilution of neutral red. Plaques were counted within $24 \mathrm{~h}$, and the virus titre was expressed as plaque-forming units ( $\mathrm{pfu} / \mathrm{ml}$ ).

\section{Immunofluorescent antibody technique}

Antibody to reo-2 was prepared by repeated i.p. inoculation on 6week-old guinea pigs with $10^{6}$ pfu of reo-2 as described previously $[9$, 11]. The $50 \%$ neutralization titre of the antiserum to reo- 2 was $1: 1000$ [11]. The $\gamma$-globulin fraction of the serum, purified by ammonium sulphate precipitation and DEAE cellulose column chromatography, was conjugated with fluorescein isothiocyanate (FITC) [12]. Unconjugated FITC was removed by gel filtration through Sephadex G-50. The labelled $\gamma$-globulin was adsorbed with acetone-treated mouse liver powder to eliminate non-specific fluorescence. The specificity of the labelled antiserum was established by an inhibition test using unlabelled antiserum to reo-2. FITC-conjugated anti-reo-2 antisera did not react with paraffin pancreas sections from uninfected NC mice. Sections of pancreas were stained with labelled antiserum as described previously [6].

\section{Virus neutralization test}

Neutralization titres were determined by incubation of $400 \mathrm{pfu}$ of virus in a volume with twofold serial dilutions of serum for $1 \mathrm{~h}$ at $37^{\circ} \mathrm{C}$. A reduction in the number of plaques by $50 \%$ served as the end 


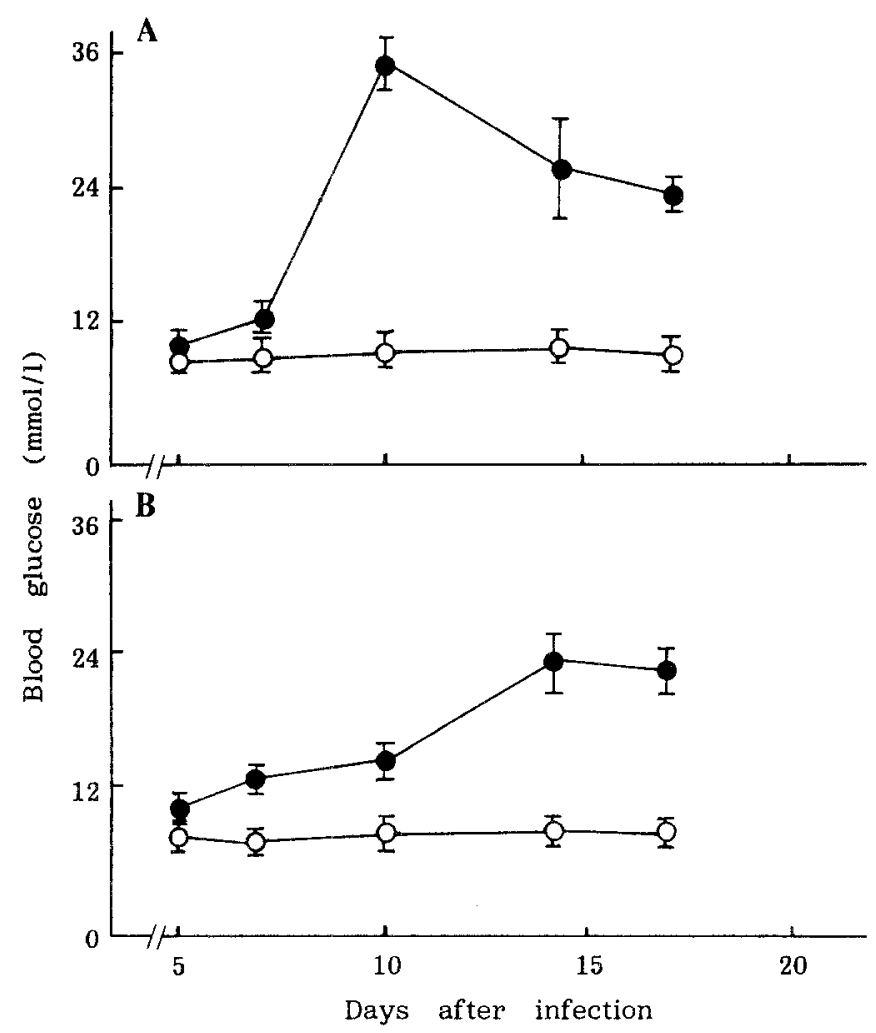

Fig. $1 \mathrm{~A}$ and B. Metabolic alterations in mice infected with reovirus type 2. Glucose tolerance tests in reovirus type 2 infected mice. Mice were infected with $1 \times 10^{5}$ pfu of virus and 60 -min glucose tolerance tests were performed on post-infection days 5, 7,10,14 and 17. Each point represents the mean and SEM of at least six mice. A, NC mice: -, reovirus-infected; $O$, uninfected. B, BALB/c mice: $\bullet$, reovirusinfected; $O$, uninfected

point. One hundred pfu of virus isolated from the pancreas of infected mice were incubated with anti-reo- 2 guinea pig antiserum to assess if the pancreata were infected with reo- 2 .

\section{Analytical methods}

Blood glucose levels and glucose tolerance tests were performed in two groups of animals (6-10 mice per group) as described previously [13]. Measurements of blood glucose levels of non-fasted animals and 60-min glucose tolerance tests (GTTs) on non-fasted animals were performed on post-infectious days 5,7,10,14 and 17. The mean non-fasting glucose level of 50 uninfected animals was $8.2 \pm$ $1.2 \mathrm{mmol} / \mathrm{l}$. In these experiments, any infected mouse with a nonfasting glucose level greater than $11.9 \mathrm{mmol} / \mathrm{l}$ ( $3 \mathrm{SD}$ above the mean) was denoted as diabetic.

The mean glucose level of GTTs in 50 uninfected animals was $9.0 \pm 0.9 \mathrm{mmol} / 1$. Any infected mouse with a glucose level greater than $11.7 \mathrm{mmol} / \mathrm{l}$ ( $3 \mathrm{SD}$ above the mean) was denoted as diabetic.

Serum immunoreactive insulin (IRI) was measured by enzymelinked immunosorbent assay procedure with porcine insulin used as the standard (Glazyme, Wako, Osaka, Japan).

\section{Immunosuppression and hormone treatments}

Rabbit anti-mouse thymocyte serum (ATS) (Ceder Lane, Ontario, Canada), with cytotoxic titre 1:1,600 was used as the immunosuppressive agent. ATS did not show the neutralizing activity against reo-2 and did not react with reo-2-infected HmLu-1 cell monolayers by indirect immunofluorescence. ATS or normal rabbit serum treatment consisted of three $0.1 \mathrm{ml}$ i.p. injections on post-infection days 0,4 and 7. Synthetic serum thymic factor (FTS, H-pyr(Glu)Ala-Lys-Ser-Gin-Gly-Gly-Ser-Asn-OH) and Arg-Lys-Asp-Val-Try (TP-5) (Mitsui Pharmaceutical Co., Tokyo, Japan) in phosphate buffered saline (PBS, $0.14 \mathrm{~mol} / 1 \mathrm{NaCl}, 2.7 \mathrm{mmol} / \mathrm{l} \mathrm{KCl}, 8.0 \mathrm{mmol} / \mathrm{l}$ $\mathrm{Na}_{2} \mathrm{HPO}_{4}, 1.5 \mathrm{mmol} / 1 \mathrm{KH}_{2} \mathrm{PO}_{4}$ ) were injected i.p. in the mice on post-infection day 14 .

\section{Statistical analysis}

Statistical significance of the differences between the mean of the sample groups was tested by Student's $t$-test with the Welch's adjustment for unequal variances where necessary [14]. The significance difference of $p<0.01$ was used as a measure of statistical significance.

\section{Results}

\section{Virus-induced metabolic alterations}

To examine whether the severity of the diabetes was dependent upon the dose of the virus, animals were inoculated with $10^{4}-10^{7}$ pfu of virus. Non-fasting blood glucose levels decreased on post-infection day $5(2.8-5.3 \mathrm{mmol} / \mathrm{l}$ in $50 \%$ of mice). Glucose levels then recovered to normal levels, but never became overtly hyperglycaemic. Approximately $20 \%$ of NC mice inoculated with $10^{4}$ pfu of virus developed diabetes using GTTs on post-infection days 14 . This increased to $80 \%$ when mice were inoculated with $10^{5} \mathrm{pfu}$ of virus. No further increase was observed when animals were inoculated with $10^{6}$ or $10^{7} \mathrm{pfu}$ of virus.

The duration of the abnormal GTTs induced by reo-2 in NC mice is illustrated in Figure 1 A. On day 14 after inoculation, the mean abnormal GTT was $24.2 \mathrm{mmol} / \mathrm{l}$ and $80 \%$ of animals manifested abnormalities. Abnormal GTTs were still apparent in some animals on post-infection day 21.

To see whether the abnormal GTTs were attributable to abnormal insulin levels, the amount of insulin in the plasma was determined at different time intervals after infection. The amount of insulin in the plasma of the infected mice with abnormal GTTs was lower than that of uninfected mice determined at each time interval (Table 1). Plasma insulin levels of the infected mice with normal GTTs were not statistically different from those of the uninfected mice.

Table 1. Immunoreactive insulin (IRI) in the plasma of reovirus type 2-infected mice

\begin{tabular}{llll}
\hline Group & \multicolumn{3}{l}{ IRI $(\mu \mathrm{U} / \mathrm{ml})$} \\
& \multicolumn{3}{l}{ Days after infection } \\
\cline { 2 - 4 } & 5 & 10 & 17 \\
\hline Uninfected & $92 \pm 3^{\mathrm{a}}$ & $96 \pm 6$ & $97 \pm 6$ \\
Infected and with abnormal GTT & $88 \pm 6$ & $82 \pm 3$ & $70 \pm 5^{\mathrm{b}}$ \\
\hline
\end{tabular}

Each group contained 8-10 NC mice infected with $1 \times 10^{5}$ pfu of reovirus type 2. ${ }^{a}$ Values for IRI are shown as mean $\pm \mathrm{SD} ;{ }^{\mathrm{b}} p<0.01$ compared with uninfected mice

GTT $=$ glucose tolerance test 


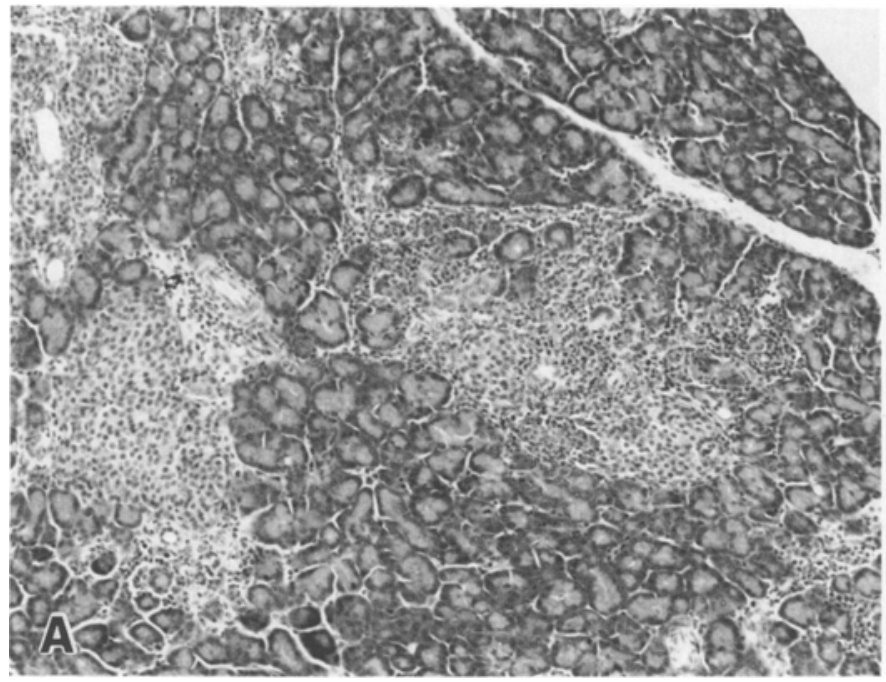

Fig. $2 \mathrm{~A}$ and B. Pathologic changes in the islet of Langerhans after infection with reovirus type 2 (haematoxylin and eosin staining). $\mathrm{NC}$ mice were infected with $1 \times 10^{5}$ pfu of virus. A Section of pancreas showing focal necrosis of pancreatic islets and infiltration of neutrophils and mononuclear round cells on post-infection day $14(\times 140)$. B Section of pancreas showing extensive necrosis and infiltration of neutrophils and mononuclear round cells with a few cells remaining intact in the central portion of the islet on post-infection day 14 $(\times 400)$

\section{Destruction of pancreatic islet cells and demonstration of viral antigens in NC mice}

To determine if abnormal GTTs were secondary responses to reo-2-induced islet cell damage, sections of pancreas from infected and uninfected mice were examined microscopically. Islets from animals infected with reo-2 revealed infiltration of neutrophiles and mononuclear cells in $80 \%$ of the islets of Langerhans (Fig. 2 A, B). Though no distinct change was seen within 7 days of infection, mild inflammatory changes were seen on post-infection day 10 , and the inflammation was maximal on day 14 . The severity of the inflammatory changes varied considerably among animals and within the pancreas with some islets showing little change while others showed moderate to extensive cell infiltration. In some areas of the pancreas, only a portion of the islet was involved. In the most severely affected areas, islet cell destruction and coagulation necrosis were observed. No acinar cell damage was observed. Atrophic islets were occasionally seen on post-infection day 21 .

To confirm that the virus was actually replicating in pancreatic Beta cells, sections from the pancreas of reo-2 infected mice were stained with FITC-labelled antibody responsive to reovirus (Fig.3). On post-infection day 5, viral antigens were seen in the cytoplasm of islet cells and occasionally in the cytoplasm of acinar cells. Maximal viral antigen distribution was observed on post-infection day 7. Haematoxylin and eosin staining revealed mild degenerative changes in the islets with viral antigens. However, viral antigens were difficult to detect in the subsequent 10 days. The degree of islet cell involvement

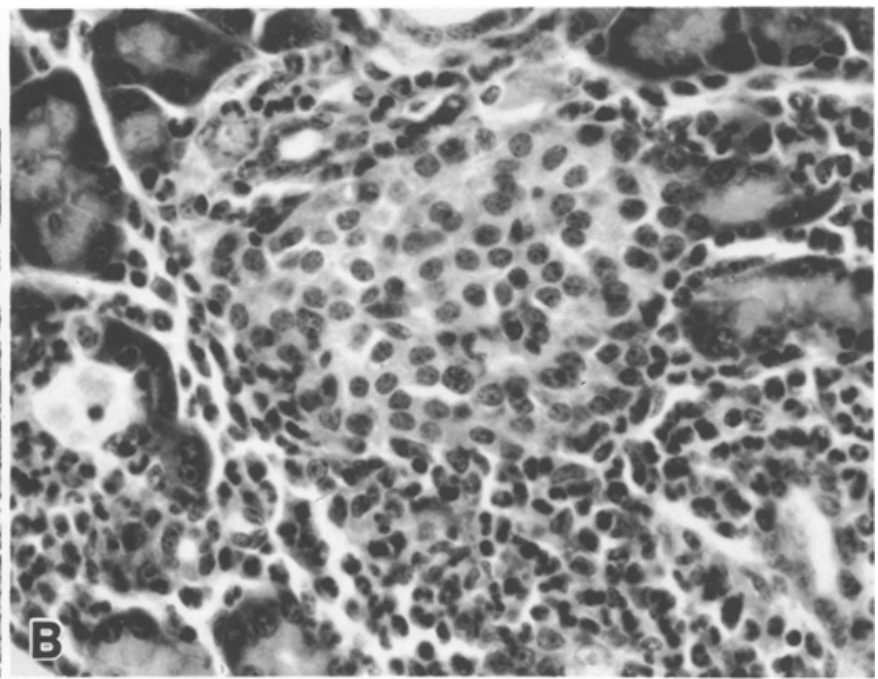

varied considerably; some islets indicated only a few cells, whereas others manifested almost all cells containing the viral antigens. Occasionally viral antigens were observed in acinar and ductal cells.

From the pancreas, $10^{2}-10^{3}$ and $10^{4}-10^{6}$ pfu of the virus per organ were recovered on post-infection days 3 and 5 , respectively. These isolated stocks of virus were completely neutralized with anti-reo-2 guinea pig serum.

\section{Mouse strain differences on the development of diabetes}

To see whether the induction of diabetes by reo-2 was influenced by the host, 2-3-day old BALB/c and CD-1 mice were infected and GTTs were performed. Figure $1 \mathrm{~B}$ shows that $\mathrm{BALB} / \mathrm{c}$ mice developed diabetes. Severity of the abnormal GTTs and the percentage of diabetes were lower in

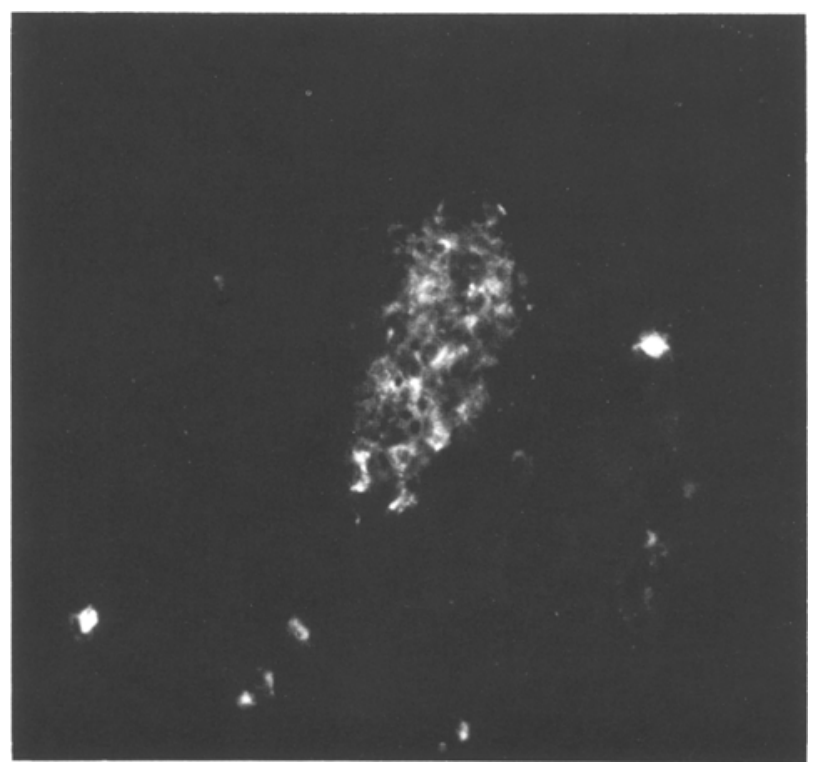

Fig.3. Reovirus type 2 antigens in the islets of Langerhans, NCmice were infected with $1 \times 10^{5}$ pfu of virus. Paraffin sections from pancreas taken on post-infection day 5 and stained with fluorescein isothiocyanate (FITC)-labelled antibody to reovirus type 2. Section of an islet with viral antigen in most of the cells where the surrounding acinar cells are relatively free of viral antigen $(\times 200)$ 
Table 2. Effects of serum thymic factor (FTS) to reovirus type 2-induced diabetes mellitus ${ }^{2}$

\begin{tabular}{lccc}
\hline Virus & FTS $(\mu \mathrm{g})$ & Blood glucose $(\mathrm{mmol} / \mathrm{l})$ & $\begin{array}{l}\text { Diabetes } \\
\%\end{array}$ \\
\hline- & - & $8.9 \pm 1.5^{\mathrm{b}}$ & 0 \\
+ & - & $17.7 \pm 1.4$ & 86 \\
+ & 10 & $9.1 \pm 0.8$ & 0 \\
+ & 1 & $9.9 \pm 0.4$ & 0 \\
+ & 0.1 & $14.3 \pm 1.8$ & 30 \\
+ & 0.01 & $19.5 \pm 4.2$ & 80 \\
- & 10 & $8.0 \pm 1.2$ & 0 \\
\hline
\end{tabular}

a Not less than $10 \mathrm{NC}$ mice in each group were infected with $1 \times 10^{5}$ pfu of reovirus type 2 and treated with FTS two weeks later. Glucose tolerance testing was performed on post-infection day 17. Statistically significant $(p<0.01)$ differences in blood glucose levels were obtained between the $10 \mu \mathrm{g}$ FTS-treated virus-infected and the FTS non-treated virus-infected groups; and the $1 \mu \mathrm{g}$ FTS-treated virus-infected andFTS non-treated virus-infected groups. ${ }^{b}$ Values for blood glucose are expressed as mean $\pm \mathrm{SD}$

Table 3. Effects of anti-thymocyte serum (ATS) to reovirus type 2induced diabetes mellitus ${ }^{\mathrm{a}}$

\begin{tabular}{llcc}
\hline Virus & ATS & Blood glucose $(\mathrm{mmol} / \mathrm{l})$ & $\begin{array}{l}\text { Diabetes } \\
\%\end{array}$ \\
\hline- & - & $9.2 \pm 0.6^{\mathrm{b}}$ & 0 \\
+ & - & $20.2 \pm 3.4$ & 60 \\
+ & + & $8.4 \pm 0.6$ & 0 \\
- & + & $9.0 \pm 0.8$ & 0
\end{tabular}

${ }^{a}$ Not less than $10 \mathrm{NC}$ mice in each group were infected with $1 \times 10^{5}$ pfu of reovirus type 2 and treated three times with ATS in two weeks. Glucose tolerance testing was performed on post-infection day 17. Statistically significant $(p<0.01)$ differences in blood glucose levels were obtained between ATS-treated virus-infected and ATS non-treated virus-infected groups. ${ }^{b}$ Values for blood glucose are expressed as mean $\pm S D$

Table 4. Effect of TP- 5 to reovirus type 2-induced diabetes mellitus ${ }^{a}$

\begin{tabular}{lclc}
\hline Virus & TP-5 $(\mu \mathrm{g})$ & Blood glucose $(\mathrm{mmol} / \mathrm{l})$ & $\begin{array}{l}\text { Diabetes } \\
\%\end{array}$ \\
\hline- & - & $10.7 \pm 0.7^{\mathrm{b}}$ & 0 \\
+ & - & $20.3 \pm 2.0$ & 90 \\
+ & 10 & $15.8 \pm 2.8$ & 67 \\
+ & 1 & $15.3 \pm 4.8$ & 40 \\
+ & 0.1 & $13.8 \pm 1.6$ & 50 \\
\hline
\end{tabular}

a Not less than $10 \mathrm{NC}$ mice in each group were infected with $1 \times 10^{5}$ pfu of reovirus type 2 and treated with TP-5 (Arg-Lys-AspVal-Try) two weeks later. Glucose tolerance testing was performed on post-infection day 17 . No statistically significant differences in blood glucose levels were obtained between TP-5-treated virus-infected and TP-5 non-treated virus-infected groups. "Values for blood glucose are expressed as mean \pm SD

CD-1 mice compared to $\mathrm{NC}$ and $\mathrm{BALB} / \mathrm{c}$. On post-infection day $14,80 \%$ of $\mathrm{BALB} / \mathrm{c}$ mice and $25 \%$ of $\mathrm{CD}-1$ mice showed abnormalities. In the majority of BALB/cand all of CD-1 mice, abnormal GTTs were transient.

\section{Suppression of diabetes by serum thymic factor and anti-thymocyte serum}

As shown in Table 2, NC mice that had been infected with reo-2 recovered from diabetes when treated i. p. with synthetic FTS at a dose of 10 or $1 \mu \mathrm{g}$. Recovery was similarly observed when FTS was injected on post-infection day 14 , when the animals began to show symptoms of diabetes. However, mice treated with 0.1 or $0.01 \mu \mathrm{g}$ FTS did not recover from the induced diabetes. ATS was tested for its effect on the development of reo-2-induced diabetes. As shown in Table 3, reo-2 produced abnormal GTTs in NC mice, but these abnormalities were reduced or prevented by the treatment with ATS. Reo-2-infected mice injected with normal rabbit sera and TP-5 (10,1 or $0.1 \mu \mathrm{g}$ doses) did not recover from the diabetes induced (Table 4).

\section{Discussion}

Our present experiments show that reo-2 can infect and damage pancreatic islet cells in certain inbred strains of mice followed by the appearance of virus antigen in pancreatic islets and abnormal GTTs. Thus, destruction of Beta cells by the virus appeared to be responsible for the abnormal results seen in GTTs. As for EMC virus and coxsackievirus $[1,5]$, the degree of islet cell damage produced by reo- 2 varies considerably among animals, even though inbred strains of mice of the same age and sex were used. This variation in Beta cells is probably responsible for the observed differences in the metabolic response of individual animals. In most of the animals, abnormal GTTs were transient. This may be due to the fact that a sufficient number of Beta cells are left intact after the infection, and proliferation of these cells results in metabolic compensation.

In the present experiments, immunosuppression with ATS greatly reduced the degree of insulitis and islet cell damage. By determination of virus growth in vivo, it is possible to evaluate that ATS prevented diabetes development by inhibiting virus replication (such as by antiviral antibody in the immunosuppressive sera or induction of interferon), rather than by suppressing the inflammation response. Virus titres in homogenates of liver, heart and pancreas were approximately the same in ATStreated and non-treated mice on post-infection days 3,5, 10 and 14. Virus isolations were negative in these organs on days 10 and 14 (data not shown). These results suggest that ATS does not inhibit virus replications. Reovirus Type 1 can cause immunopathological damage to pancreatic Beta cells $[9,16]$. Our results with reo-2 infection and immunosuppression indicate that immunological damage might be relevant to reo-2-induced diabetes.

Abnormal GTTs were also prevented by a single injection of FTS on post-infection day 14. Virus isolations on days 14 and 17 were negative in the liver, heart and pancreas of either hormone-treated or non-treated mice. This hormone has been reported to elicit many interesting immunological effects, such as in vitro and in vivo promotion of differentiation of precursor $\mathrm{T}$ cells to mature $\mathrm{T}$ cells (theta conversion), enhanced generation of alloantigen reactive cytotoxic $\mathrm{T}$ cells in thymectomized mice, induction of suppressor $T$ cells in NZB mice, prolongation of murine skin grafts, and suppression of experimental allergic encephalomyelitis (EAE) induced in guinea pigs [1720]. Guinea pigs that suffer severe paralysis with distinct incontinence from EAE recover on FTS treatment [17]. Of these immunoregulatory effects of FTS, induction of 
suppressor $\mathrm{T}$ cells is particularly interesting because it suggests that the remarkable effect of FTS that we observed is probably due to induction of suppressor T cells. We are now investigating this possibility.

Previous reports have shown $T$ cell abnormalities or imbalance, and suppressor $\mathrm{T}$ cell decrease in the peripheral blood of Type 1 diabetic patients [21,22]. FTS with the same chemical structure has been thought to exist in many animals and in humans [23]. From these previous studies on patients with Type 1 diabetes, FTS might be useful as a therapeutic agent for these cases. Metabolic alterations caused by murine pancreatic Beta-cell infection with reo2 (our present experiment) and reovirus Type 1 and 3 [8, 9] reveal the extensively disseminated viruses in human are capable of inducing a diabetes-like syndrome in mice. However, whether these viruses actually play a role in the aetiology of Type 1 diabetes is still not known.

Acknowledgements. Authors are grateful to Messrs. M. Itoh and Y.Andoh for their excellent photography. Thanks are due to Dr. A. Foong for reading the manuscripts.

\section{References}

1. Notkins AL (1977) Virus-induced diabetes mellitus - brief review. Arch Virol 54: 1-17

2. Craighead JE (1975) The role of viruses in the pathogenesis of pancreatic disease and diabetes mellitus. Prog Med Virol 19: $161-214$

3. Toniolo A, Onodera T (1983) Viruses and diabetes. In: Andreani D, Di Mario U, Federlin KF, Heding LG (eds) Immunology in diabetes. Teviot Scientific Publications, Edinburgh, pp 71-93

4. Notkins AL, Yoon JW, Onodera T, Toniolo A, Jenson AB (1981) Virus-induced diabetes mellitus. In: Pollard M (ed) Perspective in virology, Vol 11. Liss, New York, pp 141-162

5. Gamble DR, Taylor KW, Cummings H (1973) Coxsackie viruses and diabetes mellitus. Br Med J 4:260-262

6. Kurata T, Sata T, Iwasaki T, Onodera T, Toniolo A (1987) Herpes virus infection in human pancreas islets and animal models. In: Becker Y (ed) Virus infection and diabetes mellitus. Developments in medical virology. Nijhoff, Boston, pp 143-160

7. Yoon JW, Austin M, Onodera T, Notkins AL (1979) Virus-induced diabetes mellitus: isolation of a virus from the pancreas of a child with diabetic ketoacidosis. N Engl J Med 300: 1173-1179

8. Onodera T, Jenson AB, Yoon JW, Notkins AL (1978) Virus-induced diabetes mellitus: reovirus infection of pancreatic $B$ cells in mice. Science 201: 529-531

9. Onodera T, Toniolo A, Ray UR, Jenson AB, Knazek RA, Notkins AL (1981) Virus-induced diabetes mellitus XX. Polyendocrinopathy and autoimmunity. J Exp Med 153: 1457-1473
10. Kurogi H, Inaba Y, Takahashi E, Sato K, Omori T (1980) Serological relationship between Japanese strain of reovirus of bovine origin and type 2 reovirus strains. Natl Inst Anim Health Q (Japan) 20: 32-33

11. Kurogi H, Inaba Y, Takahashi E, Sato K, Goto Y, Omori T, Matsumoto M (1974) New serotypes of reoviruses isolated from cattle brief report. Arch ges Virusforsch 45: 157-164

12. Kawamura A Jr (1977) Fluorescent antibody techniques and their applications, 2nd edn. University of Tokyo Press, Tokyo

13. Ross ME, Onodera T, Brown KS, Notkins AL (1976) Virus-induced diabetes mellitus IV. Genetic and environmental factors influencing the development of diabetes after infection with the M-variant of encephalomyocarditis virus. Diabetes 25: 190-197

14. Brownlee KA (1965) Statistical theory and methodology in science and engineering. Wiley, Chichester New York

15. Yoon JW, Onodera T, Notkins AL (1978) Virus-induced diabetes mellitus XV. Beta cell damage and insulin-dependent hyperglycemia in mice infected with coxsackie virus B4. J Exp Med 148: $1068-1080$

16. Onodera T, Ray UR, Meletz KA, Suzuki H, Toniolo A, Notkins AL (1982) Autoimmunity and polyendocrine disease prevented by immunosuppression. Nature 297: 66-68

17. Nagai Y, Osanai T, Sakakibara K (1982) Intensive suppression of experimental allergic encephalomyelitis (EAE) by serum thymic factor and therapeutic implication of multiple sclerosis. Japan $\mathbf{J}$ Exp Med 52: 213-219

18. Bach JA, Dardenne M, Bach JF, Waksman BH (1976) In vitro response of rat lymphocytes following adult thymectomy III. Prevention by thymic factor of increased suppresser activity in the spleen. Cell Immunol 26: 308--312

19. Charreire J, Bach JF (1975) Binding of autologous erythrocytes to immature T-cells. Proc Natl Acad Sci USA 72: 3201-3205

20. Kaiserlian D, Dujic A, Dardenne M, Bach JF, Blanot D, Bricas E (1981) Prolongation of murine skin grafts by FTS and its synthetic analogues. Clin Exp Immunol 45: $338-343$

21. Buschard K, Madsbad S, Rygaard J (1980) Depressed suppresser cell activity in patients with newly diagnosed insulin-dependent diabetes mellitus. Clin Exp Immunol 41:25-32

22. Horita M, Suzuki H, Onodera T, Ginsberg-Fellner F, Fauci AS, Notkins AL (1982) Abnormalities of immunoregulatory T cell subsets in patients with insulin-dependent diabetes mellitus. J Immunol 129: 1426-1429

23. Bardos P, Carnard C, Bach J-F (1979) Augmentation de l'activité des cellules naturelles tueuses (cellules NK) par le facteur thymique sérique. C R Acad Sc Paris 289D: 1251-1254

Received: 21 June 1989

and in revised form: 27 November 1989

Dr. T. Onodera

Laboratory of Immune Cytology

National Institute of Animal Health

Kannondai 3-1-1, Tsukuba

Ibaraki 305

Japan 